
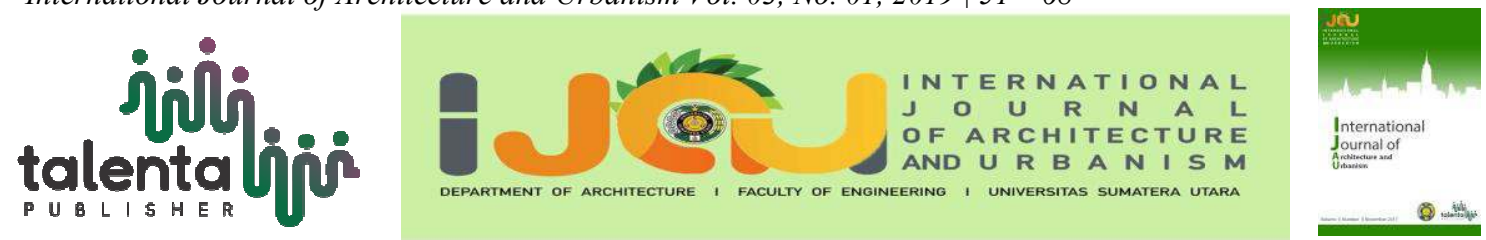

\title{
Wind Catcher and Solar Chimney Integrated As An Alternative Ventilation For Urban Dense Settlements In Tropical Climate
}

\author{
Yoka Prima ${ }^{*}$, Sugini ${ }^{1}$ \\ ${ }^{I}$ Department of Architecture, Faculty of Civil Engineering and Planning, Universitas Islam Indonesia, \\ Sleman, Yogyakarta, Indonesia
}

\begin{abstract}
The high energy use for building operations in humid tropical climates is mostly used for operational mechanical ventilation such as air conditioning (AC) and fans. The use of large amounts of energy, especially fossil energy can reduce the quality of the environment, causing an increase in the temperature of the earth. Need more efforts for management of energy use by reducing fossil energy consumption. One effort that can be done is to replace mechanical production and utilize passive ventilation in buildings. this study is a literature review regarding the use of passive ventilation using a windcatcher integrated with solarc himneys. The use of windcatcher and the solar chimney is still very rare in Indonesia, but has the potential to solve thermal problems, especially in densely populated residential areas in cities that have the character of a humid tropical climate. The results of this study recommend criteria from windcatchers and soler chimney that might be applicable and adapt to the character of the urban humid tropical climate.
\end{abstract}

Keyword: wind catcher, solar chimney, passive ventilation, urban dense settlements

\section{Introduction}

Urban population growth is increasing every year caused by birth rates and urbanization. The high of population growth is also offset by development in the form of residential buildings and other facilities. The high price of land in the city makes people always maximize land use in development and always seen in some residential or dense settlements.

Dense settlements have characteristics with buildings that stick together with other buildings and sometimes do not provide land for residual land as landscapes. Dense settlements make it a limitation by building envelopes which are usually places for ventilation as air circulation and meet thermal comfort needs.

*Corresponding author at:Jalan Kaliurang Km.14,5, Besi, Sleman, Krawitan, Umbulmartani, Ngemplak, Kabupaten Sleman, Daerah Istimewa Yogyakarta 55584

E-mail address: hermawanbayu995@gmail.com 
Humid tropical climate in cities such as those in developing countries in Indonesia has high temperatures and humidity. Some major cities in Indonesia such as Jakarta, Surabaya and the terrain have an average temperature above $27^{\circ} \mathrm{C}$ [1]. The high temperature of urban air is also exacerbated by the emergence of the urban heat island phenomenon and global warming. High temperatures in several cities in Indonesia can also be found in areas located on the equator such as Pekanbaru, Pontianak and others [2].

Thermal comfort in architectural design is a necessity because humans are involved in it as residents. Humans tend to carry out any effort to fulfill comfortable thermal needs, such as using a fan or AC. The high use of air conditioning in urban areas shows that passive ventilation is not working optimally. High intensity and limited area for openings in buildings and a dense settlement, making the wind unable to move freely so that cooling air through convection decreases [3].

To maximize the performance of passive ventilation in a dense urban environment can utilize some of the potentials of contextual conditions such as high winds and solar heat as an air driving force to maximize passive ventilation performance. One of them is by using windcatchers and a solar chimney.

This paper presents a brief review of solar ventilation and windcatcher passive ventilation and recommends how the criteria for windcatchers and solar chimney to be applied to the tropical climate of urban cities.

\section{Methodology}

This study contains a descriptive literature review of passive windcatcher and solar chimney vents based on several previous studies and then analyzed from several categories to then be developed for urban dense residential environments with humid tropical climates.

\section{Results and Discussion}

The windcatcher is a passive ventilation device that is installed on the roof or tower in a building that is used to capture external fresh air from the height of entry into the building [4]. This Windcatcher passive ventilation technology comes from countries with a dry tropical climate in the Middle East and has been used as the main passive cooling device in vernacular buildings for several centuries until now [5].

In the last 30 years, windcatcher has been extensively researched, developed and then manufactured in European countries known as modern windcatcher. Modern windcatchers have several features that cover some of the disadvantages of vernacular windcatchers such as dampers, sensors, gauges, solar panels and are integrated with enhancements such as evaporative cooling, solar-chimney and others [6]. 


\subsection{Windcatcher in a humid tropical climate}

The use of passive ventilation of windcatchers in buildings in Southeast Asian countries with humid tropical climates is very rare. some areas in humid tropical climates have high temperatures and humidity which can cause thermal problems especially in dense residential areas with limited side openings (conventional windows) in urban areas. The use of cross ventilation in buildings has always been a favorite choice used by architects / building designers as providers of thermal comfort and air circulation needs.

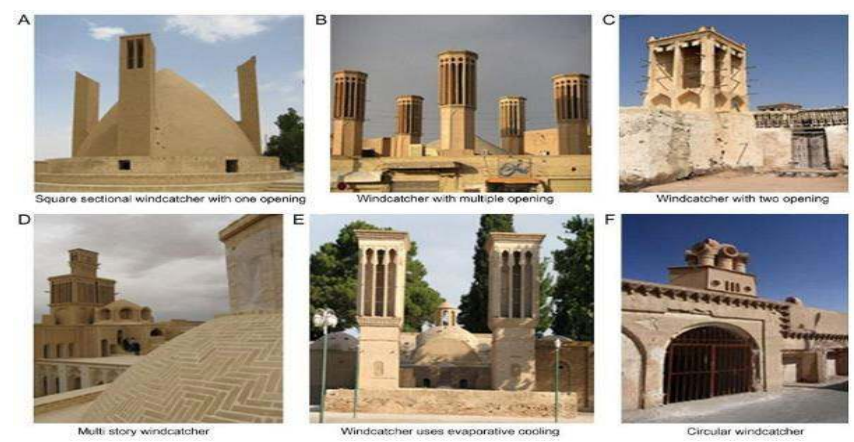

Figure 1. The Vernacular Windcatcher is Often Used in Middle Eastern Countries [6]

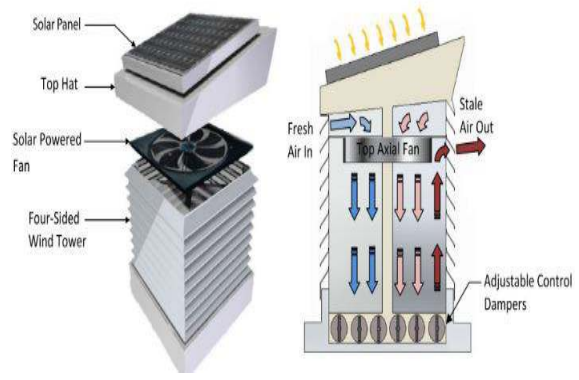

Figure 2. Modern windcatcher [14]

According to some researchers and academics, there is little use of windcatcher ventilation in southeast Asian countries such as Indonesia because the use of windcatchers in buildings can be a place for insects of dust and rainwater to enter easily into room of building, even as nesting birds. This problem is more striking in Southeast Asia and Africa where dengue hemorrhagic fever and Malaria kill thousands of people every year [6] (Figure 1).

In addition to dry tropical climates, Windcatchers can also be operated in humid tropical climates even if the wind conditions are weak. This has been proven from several studies, one of the studies is Gharakhani et al. In their research to prove the performance efficiency of windcatchers in the humid tropical climate in Malaysia and able to work in areas that have low speed wind conditions but this is also influenced by factors such as climate, weather and design from the windcatcher itself that is able to adapt to the humid tropical climate and the strategies needed to improve the performance of the windcatcher [7] (Figure 2). 


\subsection{Factors that affect the performance of the wind catcher}

There are two factors that can affect the performance of windcatchers, namely external factors and internal factors. The external factor is something that comes from outside the windcatcher device (separate) such as climate conditions, geographical location, weather and so forth. While the internal factor is something that comes from the shape of the windcatcher.

For that Windcatcher with a polygonal plan, an octagonal circle is more suitable for conditions in areas that have low wind speeds and different angles of wind that cannot be predicted. In addition to geometry, the plan size also affects the performance of the windcatcher. Increasing the plan area of the windcatcher, it can increase airflow to be greater [13]. On the inside of the windcatcher there is a Partition component that divides the windcatcher air duct into several shafts to form a grating air duct. Partitions are also often referred to as blades which have various forms such as the + blade, $\mathrm{x}$ blade, $\mathrm{H}$ blade, I blade and others (Figure 3 ).

The partition on the windcatcher serves to divide the wind tower into small shafts to increase air movement in accordance with the physical principle "Bernauly effect" where the level of air flow increases as the air passes through a narrow section. In other words, the more the number of partitions in the windcatcher can increase the airflow captured. So that windcatchers with denser partitions are an option that can be used in urban humid tropical climates and areas with low wind speeds.

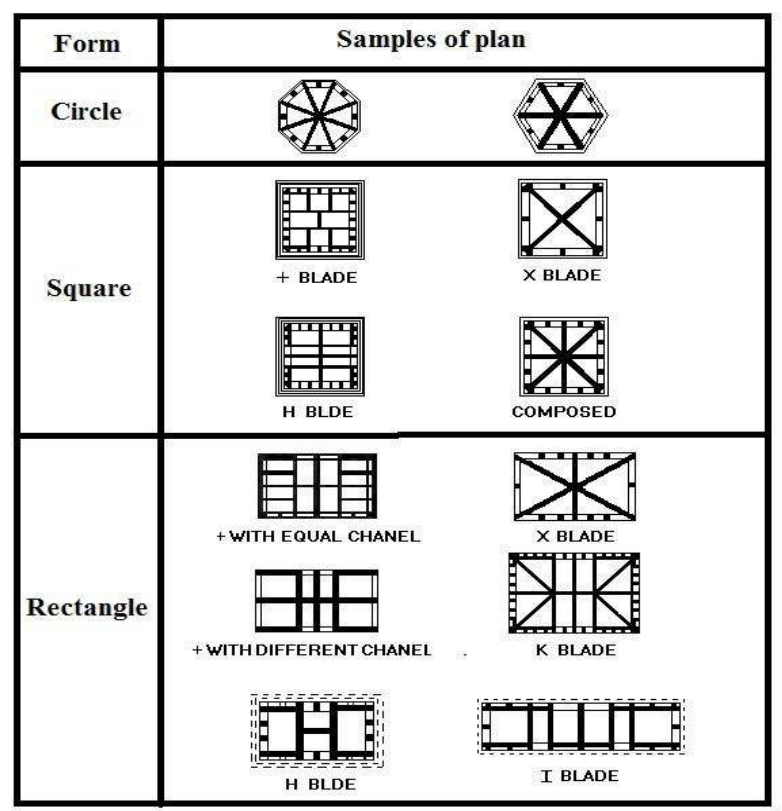

Figure 3. Various types of windcatcher layout forms [10] 

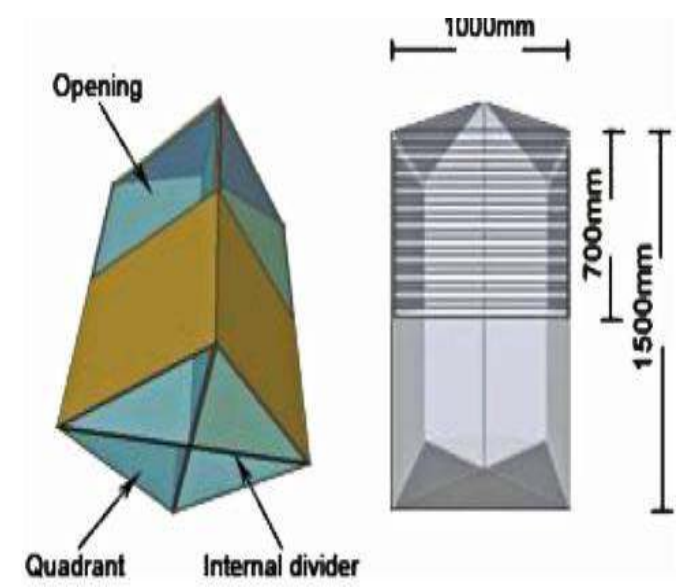

Figure 4. X partition (devider) in a modern windcatcher [30]

The height of the windcatcher has a big influence on the performance of a windcatcher [12]. According to the bahadori inside Montazeri, the higher the windcatcher, the greater the wind induction is captured and the greater the ability to minimize air or dust pollution entering the building [8]. Windcatchers usually have a height ranging between 5 and $34 \mathrm{~m}$. The highest vernacular windcatcher in the world currently has a height of $33.80 \mathrm{~m}$ located in the city of Yazd [6] (Figure 4).

In modern windcatchers there are louvre features that are often used. The Louvre is a horizontal grid mounted on a windcatcher opening. The addition of louvre to the windcatcher has the function of preventing rainwater, direct sunlight and noise outside [14]. The use of louvre is the answer to things that many people fear in considerin the use of windcatcher

Besides as protector, the use of louvre is also able to improve the performance of the windcatcher. According to Liu et al, the use of louvre can also affect the performance of the windcatcher by increasing the amount of louvre and adding a louvre display can increase windcatcher performance [15]. Installation of louvre in the windcatcher also needs to be considered the slope angle. the recommended louver tilt angle to show the best performance is $35^{\circ}-45^{\circ}$ [15] (Figure 5).

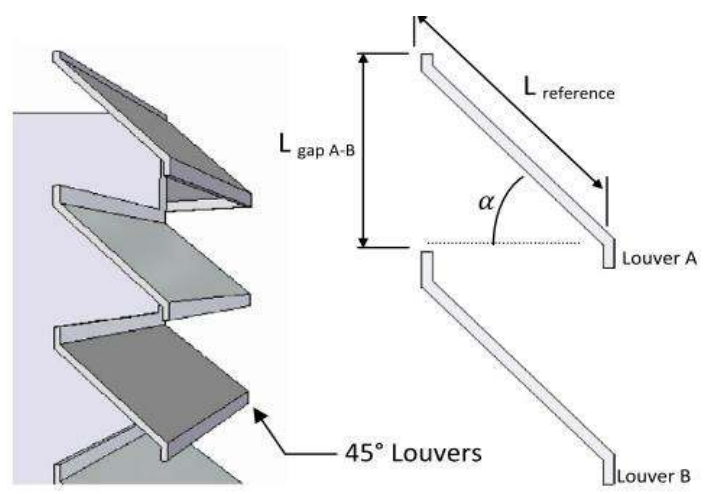

Figure 5. Windcatcher uses louvre [15] 


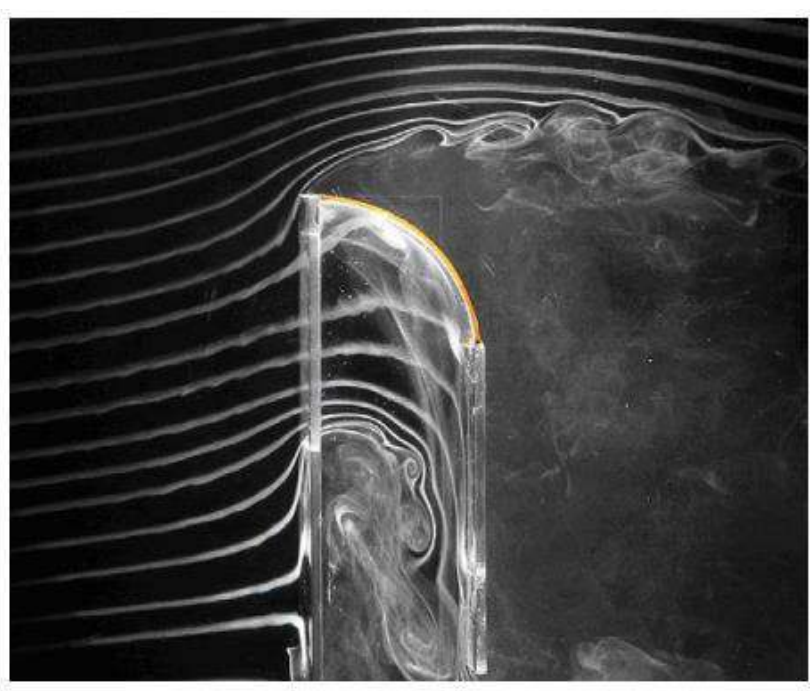

Figure 6. Windcatcher model smoke visualization test with a curved roof [16]

On the roof coverings, the windcatcher has a variety of shapes, including flat roofs, sloped roofs and curved roofs. According to Esfeh, the shape of a curved roof has the best performance that can reduce airflow resistance than other forms [16]. A similar thing was expressed by Hughes [14] (Figure 6).

\subsection{Windcatcher Performance Enhancement}

Windcatcher may sometimes be unable to work optimally under certain conditions. Because besides internal factors that influence, external factors such as climate and weather conditions can also determine the performance of the windcatcher. There are two strategies that can be used to improve the performance of windcatchers, among others, using a certain technology or additional features into the design of the windcatcher and integrating windcatchers with architectural designs.

Passive cooling technology to improve the performance of windcatchers that have been researched and developed and even used includes evaporative coolers, heat transfer devices (HTD), and underground coolers. this technology helps windcatcher performance in reducing temperatures in a room.

Evaporative Cooling is one technology that can be used to reduce indoor air temperature . Evaporative coolers are usually used in old Middle Eastern buildings to improve ventilation and thermal performance in windcatchers [14]. Besides being able to reduce the temperature, this evaporative cooler has the advantage of being able to filter dust and pollutant substances and be more economical and environmentally friendly than the use of mechanical cooling (Figure 7). 


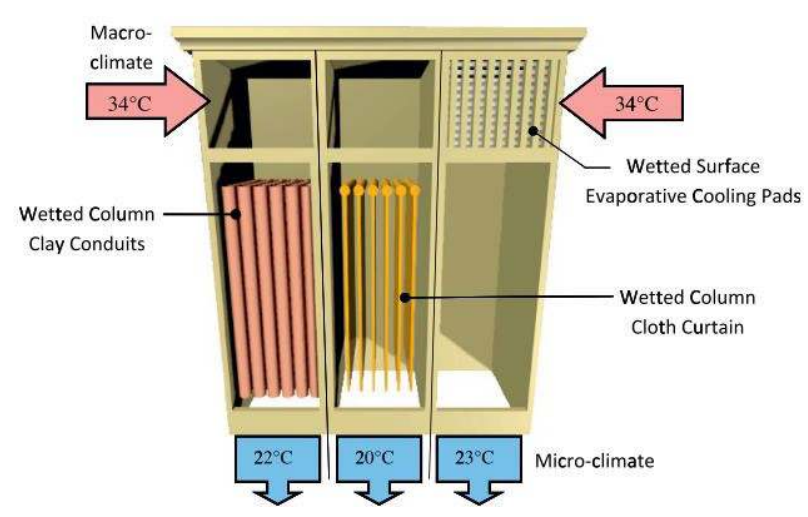

Figure 7. Thermal performance of evaporative coolers in windcatchers [14]

Heat transfer devices (HTD) are passive cooling technologies with technology developed by Calautid to overcome the shortcomings of evaporative cooling [17]. HTD has a different way of working with evaporative coolers that directly evaporate water into the air flow. HTD is an indirect cooling system using water that is inserted into a slender tube channel that lines up, HTD is installed in the windcatcher. Because the size is not large, HTD can be used for modern windcatchers [18].

Underground coolings or Earth to Air Heat Exchangers (EAHE) is a passive cooling technology that can be integrated with windcatcher ventilation. The EAHE system works by channeling warm external air towards the underground channel to transfer the heat to the ground, then the temperature of the air passing through the land channel decreases and is channeled into the room. Increasing the length of the underground channel can increase the average efficiency and temperature gradient. While increasing the channel diameter can reduce efficiency and temperature gradients [18]

In addition to passive cooling technology that can be used to improve windcatcher performance, configurations related to the integration of architectural designs are also ambiguous in improving windcatcher performance. According to Nejat \& Jomehzadeh [19], to improve the sustainable concept by maximizing natural airing performance in windcatchers, it is necessary to combine several techniques and innovations that are integrated with the windcatcher. to produce new designs. Among them are windcatchers which are integrated with courtyard (courtyard), roof dome, cross ventilation and solar chimney (sun chimney).

Architectural design that uses the court in buildings especially inner court can help improve windcatcher performance. The court that was exposed to direct sunlight for hours caused the air in the yard to warm up and rise up because of the buoyant force effect. The air captured by the windcatcher can be suctioned by the effect of this buoyancy. So that helps the performance of widcatchers if the external wind weakens [14] (Figure 8-9). 


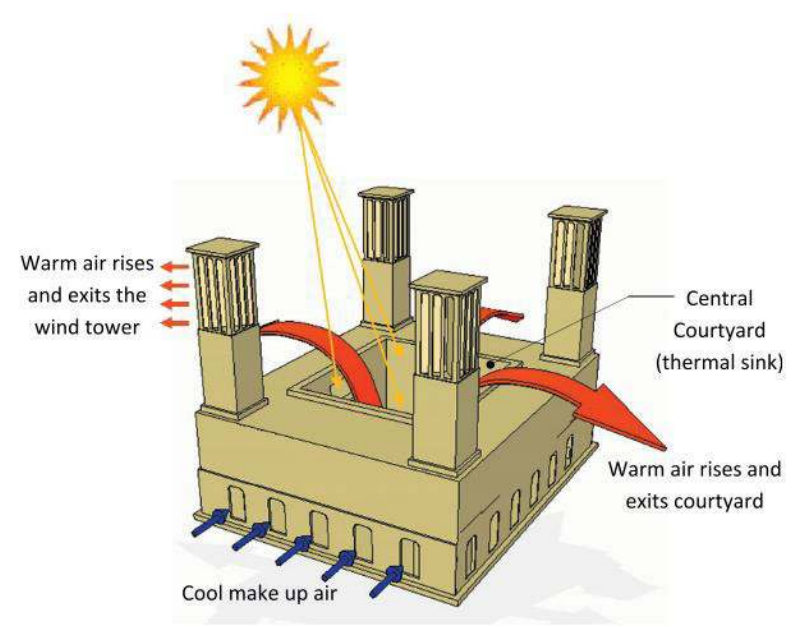

Figure 8. Windcatcher integrated with courtyard [14]

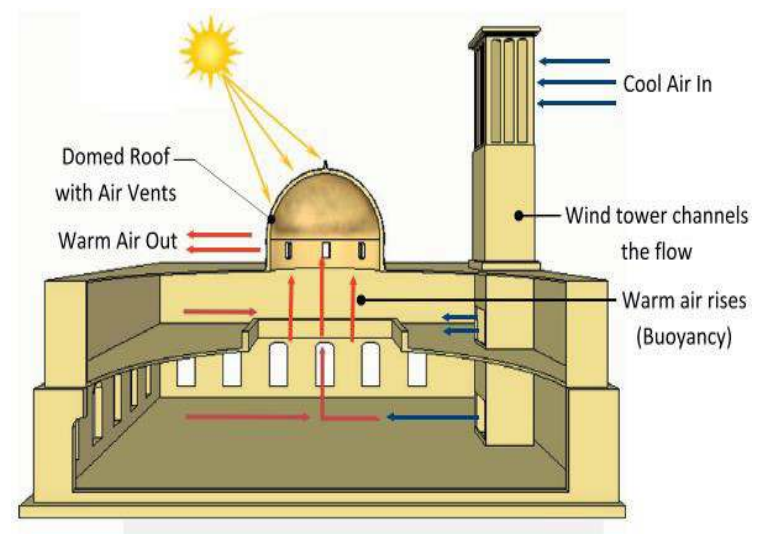

Figure 9. The windcatcher is integrated with dome roof [14]

In dry hot areas the use of dome on the roof is usually positioned on a flat roof. Because it has a wide and curved surface, the dome roof can release heat so that the dome roof can reduce temperatures faster than a flat roof [14]. In general, the use of dome roofs is a gap that is used to release air out of the building. Increasing the speed of air flowing on a curved roof lowers external pressure and pulls hot air out of the dome, then cooler air enters the window or opens the wind tower. According to Bahadori inside Hughes, a dome roof with an opening at the top is more effective when the wind blows from different directions [14].

The use of cross ventilation integrated with windcatchers can also improve the performance of windcatchers. According to Montazeri, the use of windcatchers with cross ventilation integration can affect the performance of the windcatcher. Enlarge window/openings size, it can improve the performance of the windcatcher. The window position should be at the bottom where the air enters (not in the top position) [20].

The use of windcatchers can also be integrated with solar and chimney and has also been applied with the aim of improving the performance of passive ventilation. Solar Chimney is one of the 
passive ventilation strategies that utilize air motion that has buoyancy properties. Buoyancy is produced by radiation that raises air temperature. So that air that has buoyancy moves up and out through the top of the chimney, so that air circulation can run well in a room [21].

According to Kalantar, the use of a windcatcher combined with a solar chimney device can improve the performance of a windcatcher when external wind conditions are very small [22]. The role of Solar chimney can be a secondary force in the use of windcatchers. According to Hughes, the addition of additional windows in buildings plays an important role in the performance of air vents [21]. Several studies have reported the feasibility of integrated solar chimney passive windcatcher ventilation capable of increasing cross flow ventilation and providing natural ventilation on days without hot winds [14].

\subsection{Solar chimney}

The use of solar chimney is very potential for areas with climate conditions that have high solar radiation throughout the year and areas with low wind speeds[23]. According to Joseph Khedari in Zhai et al, solar chimney ventilation can reduce the average electricity consumption of the system every day from the air conditioning system. A study in Thailand showed the level of electricity reduction ranged from $10-20 \%$ with a decrease in temperature around 8.5 degrees Celsius [23].

Solar chimney has a variety of different forms which can be selected as needed. Based on the shape and type, it can be categorized into 3 types, namely Solar Chimney wall trombe, Solar chimney Roof, Solar chimney a combination of Trombe and Roof walls as seen in figure 12 [24] (Figure 10).

Factors that affect solar chimney's performance are also similar to windcatchers, which are influenced by two factors, namely external and internal factors. External factors that comprise environmental conditions including solar radiation, external wind and climatic conditions on site sites [25] (Figure 11). 


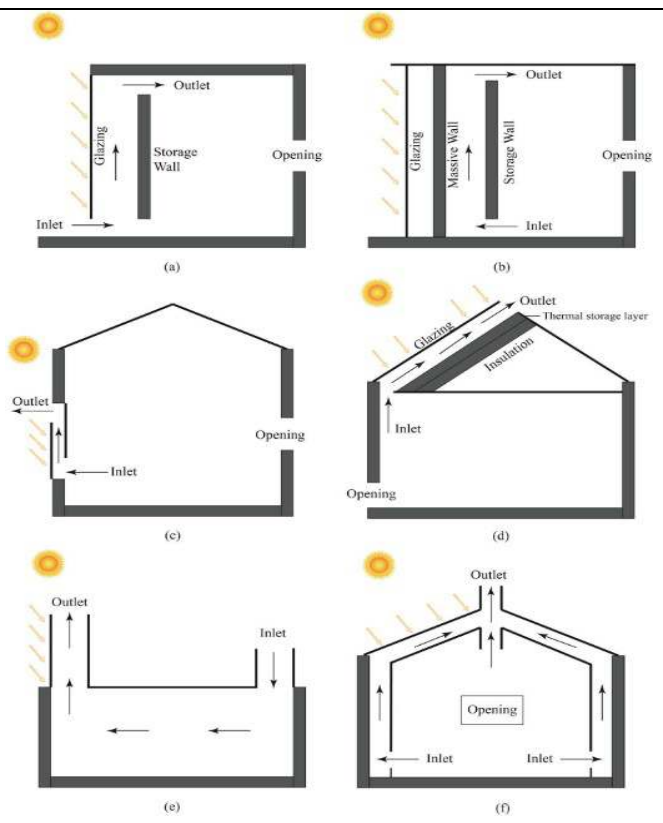

Figure 10. Solarchimney type; solarchimney with tromebe walls (a), (b), (c), solarchimney roofs (d) and (e), solarchimney combinations (f) [24]

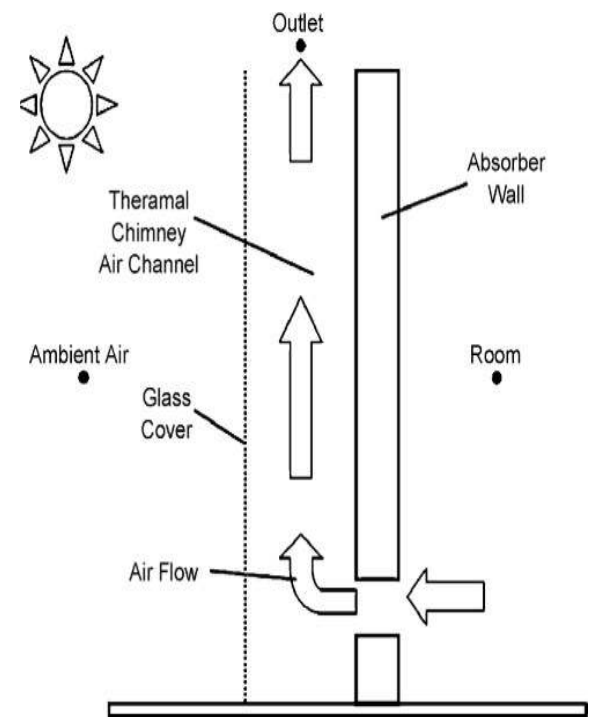

Figure 11. Solar chimney work scheme [25]

High solar radiation can improve its performance, and the volumetric flow rate shows the function of energy with solar radiation Because solar chimney is very dependent on solar radiation, it must require the right weather. While internal factors are something that can be configured in the solar chimney form and design.

The basic solar chimney design consists of three main components namely the solar collector (absorber), the ventilation shaft (air shaft) and the opening (inlet/outlet). Solar collectors are located at the top of the solar chimney or can cover the entire shaft to absorb more solar radiation[14]. Hughes also emphasized that the orientation, type of glass, insulation, thermal properties of the collector, height, cross-sectional area and thermal properties of the ventilation shaft also play a role in influencing solar chimney performance. The solar chimney is 
recommended for high. The higher the chimney the better the solar chimney performance. This is due to an increase in the difference in heat and pressure [26].

Cavity gaps in solar chimney have an influence on the performance of passive ventilation produced. The air flow rate does not always increase with a larger slot gap. This is due to backflow under uneven heating of the air in the cavity. The optimal cavity gap $0.2-0.3 \mathrm{~m}$ applies for some cases, but not all cases because it depends on other factors such as the inlet area, chimney height, and slope angle [24].

In determining cavity gap configurations also must consider the high ratio. The high ratio is the ratio between the length of the cavity and the air gap for the solar chimney roof. The recommended ratio for altitude is around 10 between the cavity height and gap for some cases [24].

In solar chimney designs, larger inlets and outlets are recommended within a certain range. The same area for inlet and outlet can increase solar chimney performance, but the use of outlets that are larger than inlets can be more efficient with improved chimney performance [24].

For solar chimney which uses a sloping plane such as a roof, it is necessary to consider the slope angle because the slope angle is the key factor to get the maximum radiation according to the latitude of the building the optimum recommended slope angle is $45-60^{0}$ [24]. In addition, the optimal angle must be considered with a balance between stack pressure and convective heat transfer. For this reason, for the solar chimney in certain locations, the optimal slope angle is higher than the angle that receives maximum solar radiation. According to Jianliu \& Weihua the $45^{\mathrm{O}}$ solar chimney slope has the best performance for Nanjing China climate [27].

According to Montazeri, increasing the number of openings in windcatchers it is very effective for areas that have different angles of wind [12]. Enlarge the window size can affect the performance of the windcatcher and can increase air velocity when the window size is raised. However, this does not apply to the position of the window on the roof of the building [20]. solar collectors on solar chimney are the most important part that can affect airflow performance. solar collector (absorber) functions to get as much heat as possible from solar radiation. Therefore, designs that support heat recovery can improve performance, such as increasing the collecting plate area and using materials with high absorption and low thermal conductivity [24]. According to El-Sawi et al inside Shi et al, the types of solar collectors have been tested, namely flat, vgrooved and chevron patterns. The solar collector with the chevron pattern was found to have the best performance, achieving up to $20 \%$ increase in thermal efficiency and an increase of $10^{\circ} \mathrm{C}$ in outlet temperatures below some flow rates [24] (Figure 12). 


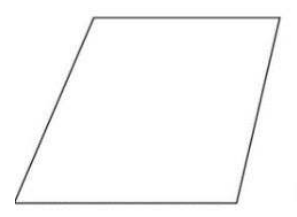

(a)

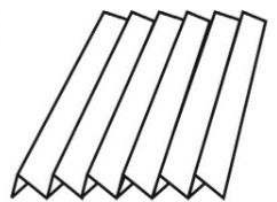

(b)

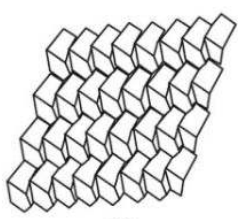

(c)

Figure 12. Solar-type absorber pattern for solar chimney roof flat; (b) V-grooved; (c) chevron pattern [24]

The absorber material is very relevant to solar chimney performance. Absorptivity and emissivity are two important properties, but absorption is more influential on solar chimney performance [28]. Some steps can improve performance during solar chimney designs using absorber with high thermal absorption properties, using patterns such as $\mathrm{v}$ grooved or chevron patterns and absorber plates with black polished surfaces [24].

In some solar chimney designs, the use of glass material can be obtained. Regarding glass selection, the nature of transmissivity, reflectivity and absorptivity is important for solar chimney performance, while transmissivity plays a more important role than the other two [24]. Double glass shows its advantages in improving the performance of solar-chimney. But it is more appropriately applied to the solar chimney as a heater than an air conditioner [24].

Thermal insulation in the solar chimney wall cavity is a significant part of increasing solar chimney performance. $5 \mathrm{~cm}$ insulation wall thickness is recommended when considering costs because it does not provide a significant reduction in performance when comparing with insulation walls with a thickness of more than $10 \mathrm{~cm}$ [24].

\subsection{Solar chimney performance enhancement}

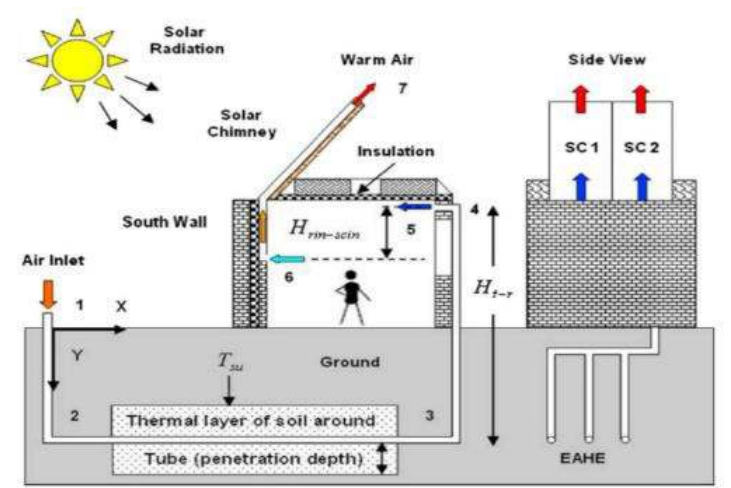

Figure 13. The solar chimney work scheme is integrated with EAHE as an air conditioner [29] 


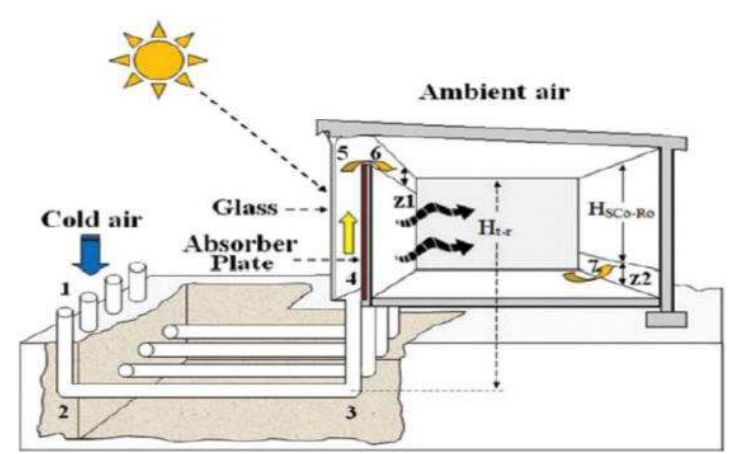

Figure 14. The solar chimney work scheme is integrated with EAHE as an air heater [29]

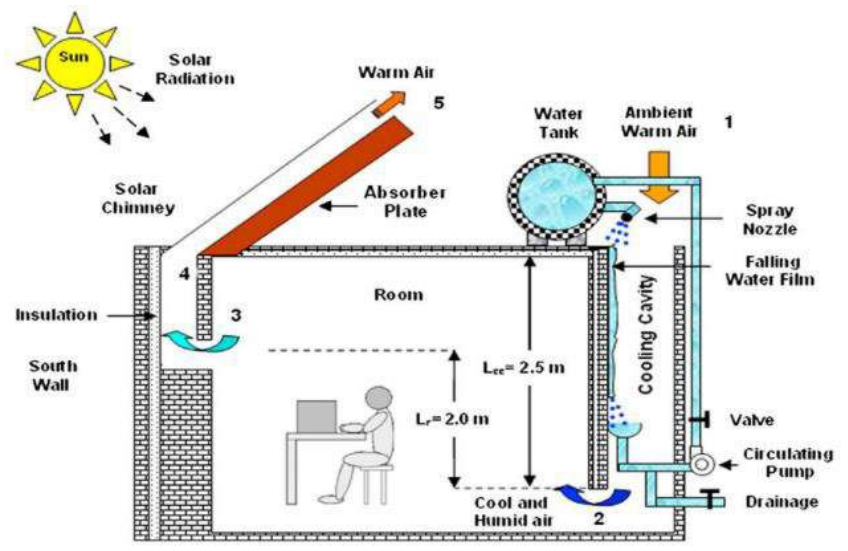

Figure 15. Solar chimney integrated cooling cavity [29]

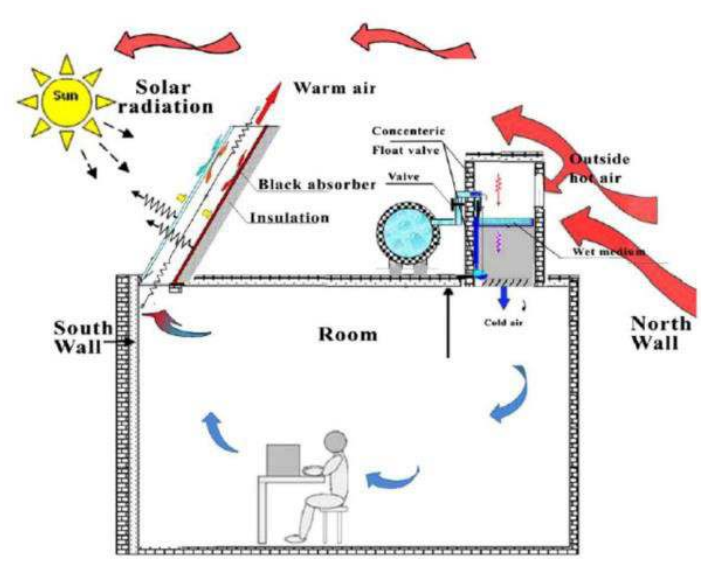

Figure 16. the solar chimney is integrated with evaporative cooler wind tower [29]

The performance of solar chimney can be improved through the addition of features and integration of passive cooling technology including earth-air heat exchangers, an innovative technique that circulates the outside air using channels buried under the ground to utilize low soil temperatures during summer and high when winter. So that this system can be used to improve the performance of solar chimney both working as a heater and air conditioner [29] (Figure 13 $16)$. 
In addition to underground cooling, the solar chimney can also be integrated with Phase change Materials (PCM). PCM is thermal management capable of storing and releasing heat energy during the fusion or freezing process. When the material freezes, it releases large amounts of energy in the form of heat. As much as when PCM is melted, the amount of energy from around the environment can be absorbed [29]. According to Kosny J in Monghasemi PCM in building envelope can be used as a strategy to reduce energy consumption in meeting the needs of conditional water with a variety of different objectives such as heat storage, ventilation and insulation [29]. Like windcatchers, the use of solar chimney can also be integrated with evaporative coolers using a cooling cavity and water spray system.

\subsection{The windcatcher is integrated with solar chimney}

In the theory of ventilation there are two main forces capable of driving wind, namely wind pressure and buoyancy. One effort to improve the passive ventilation performance of windcatchers is to integrate with several cooling technologies and other strategies in the form of architectural design elements, such as courtyards, dome roofs, cross ventilation and a solar chimney.

To maximize the performance of the windcatcher and adjust it to the urban humid tropical climate conditions that have low wind speeds, it can combine windcatchers with solar chimney vents (Solar chimney). The windcatcher strength can be increased by utilizing the buoyancy effects caused by temperature differences [21]. Research on windcatchers combined with solar chimney has been carried out by previous studies of various climatic conditions. where the results of the study indicate that the combination between the two makes passive ventilation more efficient which can increase the air flow rate [22] (Figure 17).

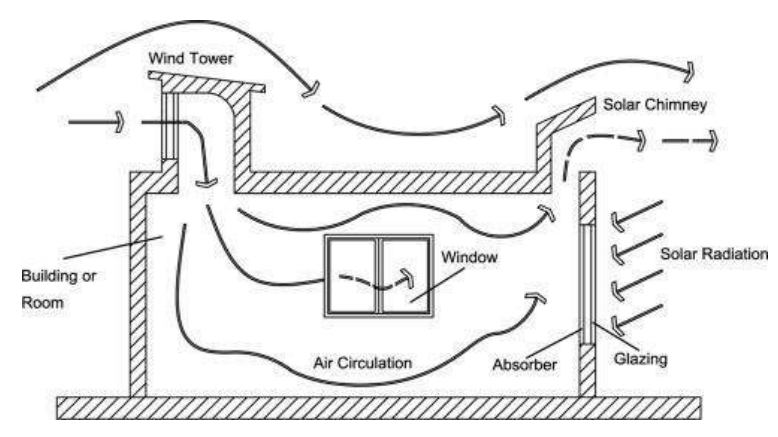

Figure 17. Windcatcher and solar chimney work schemes [22]

The results of the exposure of windcatchers and solar chimney based on the literature can be grouped and formulated for recommendations to consider passive ventilation design using windcatchers integrated with solar chimney for urban tropical climate characteristics based on influencing factors from elements of windcatcher and solar chimney elements. be as follows (Table 1) : 
Table 1. Windcatcher

\begin{tabular}{|c|c|c|}
\hline No & Attribute & $\begin{array}{l}\text { Recommended criteria for humid tropical climate } \\
\text { in cities }\end{array}$ \\
\hline 1 & Openings & Multi-direction openings \\
\hline 2 & $\begin{array}{l}\text { Form of } \\
\text { plan }\end{array}$ & Polygonal, octagonal and circle \\
\hline 3 & Plan size & The bigger, the better \\
\hline 4 & $\begin{array}{l}\text { Number of } \\
\text { Partitions }\end{array}$ & The more, the better \\
\hline 5 & Height & The higher the better \\
\hline 6 & Protector & Use louvre with the mounting angle $35^{\circ}-45^{\circ}$ \\
\hline 7 & $\begin{array}{c}\text { The form } \\
\text { of roof } \\
\text { cover }\end{array}$ & Curved \\
\hline
\end{tabular}

Table 2. Solar chimney

\begin{tabular}{ccc}
\hline No & Attribute & The higher the better \\
\hline $\mathbf{1}$ & Height & The higher, the better \\
\hline $\mathbf{2}$ & Cavity gap & $\begin{array}{c}\text { There needs to be an arrangement (further research to } \\
\text { find out in certain case conditions }\end{array}$ \\
\hline $\mathbf{3}$ & High ratio & $\begin{array}{c}\text { There needs to be an arrangement (further research } \\
\text { to find out in certain case conditions }\end{array}$ \\
\hline $\mathbf{4}$ & Inlet/outlet & $\begin{array}{c}\text { The outlet is bigger than the } \\
\text { inlet }\end{array}$ \\
\hline $\mathbf{5}$ & Tilt angle & $\begin{array}{c}45-60^{\circ} \text { but it depends on orientation, the position } \\
\text { of the building against the sun. To get maximum } \\
\text { solar radiation }\end{array}$ \\
\hline $\mathbf{7}$ & Openings & $\begin{array}{c}\text { Increase the number of } \\
\text { openings better }\end{array}$ \\
& Absorber & The chevron pattern or $\mathbf{v}$ grooved pattern with \\
& &
\end{tabular}

Based on several previous literature reviews, there are many cooling strategies and passive ventilation that can be used. But by looking at the characteristic conditions of dense settlements located in urban areas, especially cities that have thermal problems that are characterized by high 
temperatures and humidity, integrated windcatchers with solar fuel are alternative alternatives that are highly compatible passive use. Because in addition to being able to respond to the problems of side openings (due to maximum land use) it is also able to improve the performance of passive ventilation rather than the use of side openings (conventional windows) (Table 2).

\section{Conclusion}

This study presents literature review on passive ventilation that is rarely found in buildings in Indonesia. Passive windcatcher and solar chimney ventilation have the potential to be developed by looking at the climatic conditions and development conditions, especially the current urban settlement. In this study also provides recommendations for passive windcatcher and solar chimney ventilation designs that can be applied to the characteristics of urban humid tropical climates. But for more measurable results, further studies need to be developed that can be developed such as design proposals to simulations.

\section{Acknowledgement}

This paper is a brief literature review of wind catchers and solar chimney discussed based on factors that affect their performance and also recommend how the character of the design of windcatchers and solar chimney for the humid urban tropical climate.

\section{REFERENCES}

[1] T. H. Karyono, Wujud Kota Tropis di Indonesia : Suatu Pendekatan Iklim, Lingkungan dan Energi, Dimens. Tek. Arsit., 2001.

[2] L. Tursilowati, Urban Heat Island dan Kontribusinya pada Perubahan Iklim dan Iklim dan Hubungannya dengan Perubahan Lahan Urban Heat Island ( UHI ) dicirikan seperti ‘ pulau ' udara permukaan panas yang terpusat suburban / rural ( gambar 1 . 1 ), Urban Heat Island, April 2015.

[3] R. Priyadarsini, W. N. Hien, and C. K. Wai David, Microclimatic modeling of the urban thermal environment of Singapore to mitigate urban heat island, Sol Energy, 2008.

[4] M. N. Bahadori, Passive Cooling Systems in Iranian Architecture," vol. 238, no. 2, pp. 144-154, Sci. Am., 1978.

[5] Y. Bouchahm, F. Bourbia, and A. Belhamri, Performance Analysis and Improvement of the Use of Wind Tower in Hot Dry Climate, Renew. Energy, 2011.

[6] O. Saadatian, L. C. Haw, K. Sopian, and M. Y. Sulaiman, Review of Windcatcher Technologies vol. 16, no. 3, pp. 1477-1495, Renew. Sustain. Energy Rev., 2012.

[7] E. S. M. R. a. H. B. S. A. Gharakhani, "Experimental Study on Perfomance of Wind Catcher in Tropical Climate vol. 12, no. 8, pp. 2551-2555, ARPN J. Eng. Appl. Sci., 2017.

[8] H. Montazeri, Experimental and numerical study on natural ventilation performance of various multi-opening wind catchers vol. 46, no. 2, pp. 370-378, Build. Environ., 2008. 
[9] M. Dehnavi, M. H. Ghadiri, H. Mohammadi, and H. Ghadiri, Study of Wind Catchers with square plan : Influence of physical parameters vol. 2, no. 1, pp. 559-564., Int. J. Mod. Eng. Res, 2012.

[10] H. Montazeri, Experimental and numerical study on natural ventilation performance of various multi-opening wind catchers vol. 46, no. 2, pp. 370-378, Build. Environ., 2011.

[11] G. M. H. a. M. Dehnavi, The Effect of Plan Size in Wind Catcher," no. FEBRUARY, pp. 10-14, 2015., 2015.

[12] J. K. C. a. S. A. G. B. R. Hughes, The development of commercial wind towers for natural ventilation: A review, vol. 92, pp. 606-627, Appl. Energy, 2012.

[13] C. M. M. a. J. L. N. S. Liu, Numerical evaluation of louver configuration and ventilation strategies for the windcatcher system vol. 46, no. 8, pp. 1600-1616, Build. Environ., 2011.

[14] M. K. Esfeh, A. A. Dehghan, M. D. Manshadi, and S. Mohagheghian, Visualized flow structure around and inside of one-sided wind-catchers vol. 55, pp. 545- 552, Energy Build., 2012.

[15] J. K. Calautit, B. R. Hughes, and S. S. Shahzad, CFD and wind tunnel study of the performance of a uni-directional wind catcher with heat transfer devices vol. 83, no. November, pp. 85-99, Renew. Energy, 2015.

[16] F. Jomehzadeh et al., A review on windcatcher for passive cooling and natural ventilation in buildings, Part 1: Indoor air quality and thermal comfort assessment vol. 70, pp. 736756, Renew. Sustain. Energy Rev., 2017.

[17] P. Nejat and F. Jomehzadeh, Windcatcher as a Persian Sustainable Solution for Passive Cooling vol. 6, no. 1, pp. 1-4, 2018.

[18] H. Montazeri and F. Montazeri, CFD simulation of cross-ventilation in buildings using rooftop wind-catchers: Impact of outlet openings vol. 118, pp. 502- 520, Renew. Energy, 2018.

[19] B. R. H. a. C. M. Mak, A study of wind and buoyancy driven flows through commercial wind towers vol. 43, no. 7, pp. 1784-1791, Energy Build., 2011.

[20] V. Kalantar, Numerical simulation of cooling performance of wind tower (Baud-Geer) in hot and arid region vol. 34, no. 1, pp. 246-254, Renew. Energy, 2009.

[21] X. Q. Zhai, Z. P. Song, and R. Z. Wang, A review for the applications of solar chimneys in buildings vol. 15, no. 8, pp. 3757-3767, Renew. Sustain. Energy Rev., 2011.

[22] G. Z. W. Y. D. H. X. C. a. S. S. L. Shi, Determining the influencing factors on the performance of solar chimney in buildings vol. 88, no. January 2017, pp. 223-238, Renew. Sustain. Energy Rev.,, 2018.

[23] K. H. Lee and R. K. Strand, Enhancement of natural ventilation in buildings using a thermal chimney vol. 41, no. 6, pp. 615-621, Energy Build., 2009.

[24] L. Shi, G. Zhang, W. Yang, D. Huang, X. Cheng, and S. Setunge, Determining the in fluencing factors on the performance of solar chimney in buildings vol. 88, no. March, pp. 223-238, Renew. Sustain. Energy Rev., 2018.

[25] X. J. a. L. Weihua, Study on solar chimney used for room natural ventilation in Nanjing 
vol. 66, pp. 467-469, Energy Build, 2013.

[26] W. Rattanongphisat, P. Imkong, and S. Khunkong, An Experimental Investigation on the Square Steel Solar Chimney for Building Ventilation Application vol. 138, pp. 1165-1170, Energy Procedia, 2017.

[27] N. Monghasemi and A. Vadiee, A review of solar chimney integrated systems for space heating and cooling application vol. 81, no. October 2016, pp. 2714-2730, Renew. Sustain. Energy Rev., 2017.

[28] A. R. Dehghani-Sanij, M. Soltani and K. Raahemifar, A new design of wind tower for passive ventilation in buildings to reduce energy consumption in windy regions vol. 42, pp. 182-195, Renew. Sustain. Energy Rev., 2015. 